\title{
ENERGY CONVERGENCE OF THE EUROPEAN UNION TOWARD
} 2020

\section{Tekla SEBESTYÉN SZÉP}

${ }^{a}$ Institute of World and Regional Economics, Faculty of Economics, University of Miskolc, address: 3515 Miskolc-Egyetemváros, Hungary, +36 20-561-6682, regtekla@uni-miskolc.hu

Cite this article: Sebestyén Szép, T. (2016). Energy convergence of the European Union toward 2020. Deturope, 8, 3: 88-107

\begin{abstract}
The European Union set three goals (for energy efficiency, share of renewable energy sources, and greenhouse gas emissions) in the Energy 2020 document emphasising the importance of joint actions. This study investigates the 28 members' progression in the light of these commitments, between 2001 and 2012. Applying the methodology of sigma and beta convergence, we prove the convergence progress across the member states, but the result of gamma convergence modifies it: we conclude that differences remained in the European Union between 2001 and 2012 but the extent of the differences decreased significantly. The renewables ratio shows the fastest convergence rate. With energy intensity and emissions these positive processes are affected negatively by the financial crisis, causing temporary divergence. Calculating convergence clubs raises awareness of differences between the old and new member states.
\end{abstract}

Keywords: energy, energy intensity, renewables, greenhouse gas emissions, convergence, Energy 2020 strategy, European Union

\section{INTRODUCTION}

As 2020 approaches nearer, the European Union should carry out an interim review about the Energy 2020 objectives. Accordingly, in this study we particularly aim to: a) test the assumption that the energy indicators (energy intensity, emissions, and the share of the renewable energy sources) in the member states of the European Union is converging; b) prove that there are significant differences between the old and the new members in convergence processes; c) test our assumption that the members can be organized into convergence clubs.

The question may arise why the convergence analysis of the energy features of the EU member states is important. First, the political decision makers have to know the potential shifts of the energy indicators in the future. This can help to create the conditions for efficient energy management and making forecast models. The topic of decoupling is also very popular nowadays. If the countries with high energy intensity converge to the more developed ones, 
the equilibrium value will be lower; at that time with rapid convergence and balanced economic development, suddenly increasing energy use is not expected (Markandya et al. 2006).

\section{Theoretical background}

Economics very frequently takes over methods from other academic disciplines, but this can also be observed within economics: the boundaries of the competing topics are blurring, and methods are sometimes applied in another context. Quah (1995, p.5) notes about the application of the convergence calculations that "examples show that convergence is simply a basic empirical issue, one that reflects on - among other things - polarization, income distribution, and inequality. Certainly, understanding economic growth is important. But growth is only one of many different areas in economics where analyzing convergence sheds useful insight." The topic of convergence across economies is a focus in Barro (1991) and Barro and Sala-i Martin (1992). Nowadays not only the researchers of world and regional economics (for example Benedek and Veress 2013, Kocziszky 2011, Szendi 2013), spatial economics (such as Tóth and Nagy 2014), but researchers of energy, environmental and ecological economics focus on it as well (such as Szlávik 2013).

According to Oblath and Szörfi (2008, p.205), "the convergence - in a narrower sense means the catching up of the real economy performance of the less developed country to the more developed ones". In a wider sense it is the approach of general macroeconomic characteristics. Convergence calculation methods are applied in many research areas as a frequently used tool for the examination of poverty, income inequality, and human development. We can find convergence calculations in energy and environmental economics for less than one decade, but despite this short time period, many studies (Table 1) and new approaches have appeared and serious development can be observed in the data and methodology applied. 
Table 1 Energy convergence in the literature

\begin{tabular}{|c|c|c|c|}
\hline Publication & $\begin{array}{c}\text { Examined } \\
\text { country group } \\
\text { and time period }\end{array}$ & Indicator & Methodology \\
\hline $\begin{array}{l}\text { Markandya et al. } \\
(2006)\end{array}$ & $\begin{array}{c}\text { EU-27, 1992- } \\
2002 \\
\end{array}$ & energy intensity & $\begin{array}{l}\text { conditional } \beta- \\
\text { convergence }\end{array}$ \\
\hline Ezcurra (2007) & $\begin{array}{c}98 \text { countries, } \\
1971-2001 \\
\end{array}$ & energy intensity & $\begin{array}{c}\sigma \text {-convergence, other } \\
\text { non-parametric methods }\end{array}$ \\
\hline Liddle (2009) & $\begin{array}{l}22 \text { IEA members, } \\
1960(1973)-2005\end{array}$ & intensity of electricity use & $\sigma$ és $\gamma$-convergence \\
\hline Liddle (2012) & $\begin{array}{c}28 \text { OECD } \\
\text { members, } 1960- \\
2006\end{array}$ & energy intensity & $\begin{array}{l}\sigma, \text { absolut } \beta \text {, and } \gamma- \\
\text { convergence }\end{array}$ \\
\hline $\begin{array}{l}\text { Mohammadi and } \\
\text { Ram (2012) } \\
\end{array}$ & $1971-2007$ & $\begin{array}{c}\text { energy and electricity use per } \\
\text { capita }\end{array}$ & $\begin{array}{c}\sigma \text { and absolut } \beta- \\
\text { convergence }\end{array}$ \\
\hline $\begin{array}{l}\text { Mulder and Groot } \\
\text { (2012) }\end{array}$ & $\begin{array}{l}18 \text { OECD } \\
\text { members, } 1970- \\
2005\end{array}$ & energy intensity & $\begin{array}{c}\sigma \text { and conditional } \beta- \\
\text { convergence }\end{array}$ \\
\hline Hajko (2012) & $\begin{array}{l}\text { EU-27, 1990- } \\
2008 \\
\end{array}$ & energy intensity & $\begin{array}{c}\sigma, \text { conditional } \beta \text {, and } \gamma- \\
\text { convergence }\end{array}$ \\
\hline Burnett (2013) & $\begin{array}{l}\text { USA member } \\
\text { states, } 1960-2009\end{array}$ & $\mathrm{CO}_{2}$ emission & $\begin{array}{l}\text { conditional } \beta- \\
\text { convergence, } \\
\text { convergence club }\end{array}$ \\
\hline $\begin{array}{l}\text { Camarero et al. } \\
\text { (2013) }\end{array}$ & $\begin{array}{c}23 \\
\text { OECDmembers, } \\
1960-2008\end{array}$ & $\begin{array}{l}\text { emission intensity, carbonization } \\
\text { index }\left(\mathrm{CO}_{2} \text { emissions relative to }\right. \\
\text { energy use), energy intensity }\end{array}$ & convergence club \\
\hline $\begin{array}{l}\text { Meng et al. } \\
\text { (2013) }\end{array}$ & $\begin{array}{c}25 \text { OECD } \\
\text { members, } 1960- \\
2010\end{array}$ & energy use per capita & $\begin{array}{l}\text { conditional } \beta \text { - } \\
\text { convergence }\end{array}$ \\
\hline $\begin{array}{l}\text { Adhikari and } \\
\text { Chen (2014) }\end{array}$ & $\begin{array}{c}35 \text { Asian } \\
\text { countries, } 1993- \\
2010 \\
\end{array}$ & $\begin{array}{c}\text { energy productivity (GDP relative } \\
\text { to energy use) }\end{array}$ & $\begin{array}{l}\sigma \text { and } \beta \text {-convergence } \\
(\text { absolut and } \\
\text { conditional) }\end{array}$ \\
\hline $\begin{array}{l}\text { Csereklyei et al. } \\
\qquad(2014)\end{array}$ & $\begin{array}{l}99 \text { countries, } \\
1971-2010\end{array}$ & $\begin{array}{l}\text { energy use per capita, energy } \\
\text { intensity, income per capita, } \\
\text { energy/capita ratio }\end{array}$ & $\begin{array}{l}\sigma \text { and absolut } \beta- \\
\text { convergence }\end{array}$ \\
\hline $\begin{array}{l}\text { Moutinho et al. } \\
\text { (2014) }\end{array}$ & $\begin{array}{l}\text { Portugal, 1996- } \\
2009\end{array}$ & emission intensity & $\begin{array}{l}\sigma, \beta(\text { absolute and } \\
\text { conditional) and } \gamma- \\
\text { convergence }\end{array}$ \\
\hline
\end{tabular}

Source: own compilation

The study of Mielnik and Goldemberg (2000) launched the application of convergence calculations to the field of energy. They examined the energy intensity of 41 countries between 1971 and 1992. However, their analysis was made with simple description statistics and using diagrams. Markandya et al. examined the energy intensity in the European Union, with regard to the group of the old (15 countries) and the new (those joining in 2004 and 2007) member states. The center of their study is the target of 20\% (Energy 2020) and the evaluation of the implementation process. Their results verify their starting hypothesis: the catching up of the new members is successful from the energy perspective. Ezcurra (2007) 
found declining convergence across 98 countries between 1971 and 2001 as judged by energy intensity.

Energy intensity is also focused upon in the study of Liddle (2012). The $\sigma$, absolute $\beta$, and the $\gamma$-convergence were verified in the case of 28 OECD countries. In a previous publication (Liddle 2009) not the energy intensity but the electricity consumption relative to GDP was examined for 22 developed IEA members. An interesting feature of this study is that the calculations were made not on the level of the national economy, but on the level of trade, industry, and household sectors.

Moutinho et al. (2014) and Mulder and Groot (2012) conduct their analyses - similar to Liddle (2009) - at the sectoral level as well. In Mulder and Groot (2012) study the $\sigma$ and the $\gamma$-convergence were verified in the service sector and manufacturing industry.

Csereklyei et al. (2014) took a much larger sample compared with the previous studies into consideration. The convergence in energy intensity was proved for 99 countries between 1971 and 2010. However, in some regions (the Middle East and Africa) rather divergence was verified.

As in our analysis, Burnett (2013) and Camarero et al. (2013) determined convergence clubs to prove the convergence in emission rates as well. The study of Hajko (2012) can be considered as a precedent for our analysis. The researcher calculated the $\sigma$ and the $\beta$ convergence in the energy intensity for the 27 members of the European Union. "It is found that even by the rough distinction between the new and the old member countries, the convergence in energy intensity in new member countries can be found" (Hajko 2012, p. 3).

However, our current study goes beyond those limits. On the one hand our most important objective is to analyse and evaluate the achievement of 20-20-20 goals (by the 28 members of the European Union). It is served by the change of the examined time period, which contributes to take into consideration the effects of 2008-2009 financial crises. The applied convergence methods were also expanded to get a much clearer and fuller picture of the current processes.

\section{OBJECTIVES AND METHODS}

In this study, convergence is approached in three ways: $\sigma, \gamma$, and $\beta$-convergence are calculated and based on the calculations the convergence clubs are determined. Hereinafter the methodology is presented. 
Calculating the $\sigma$-convergence, we can conclude the convergence or divergence from the dispersion of the national cross-sectional data. If the value of the coefficient of variation (CV) is decreasing over time, the $\sigma$-convergence is verified across the countries. Actually, the $\sigma$ convergence presents the efficiency of the catching up of the low-performing countries with the developed countries (Liddle 2012). One disadvantage of the indicator is that it is an absolute one, the value even higher when only the absolute size increases. The $\sigma$-convergence is calculated with the $\mathrm{CV}$, which is the ratio of the dispersion and simple aritmethric average of the data (Moutinho et al. 2014).

It can happen that the value of the $\sigma$-convergence consistently decreases (so the examined territorial units converge), but the position of the nations with the highest and lowest values do not change in the sample. Boyle and McCarthy (1997a, 1997b) worked out the $\gamma$ convergence to consider the rank of the nations. The closer the index value is to zero the greater the extent of the mobility within the distribution. The $\gamma$-convergence is suitable for the measurement of intra-distribution mobility: the country with lower initial level of the selected indicator - if catching up is successful - moves up in the ranking and overtakes the developed ones (which lose their positions). A lack of $\gamma$-convergence coupled with a substantial $\sigma$-convergence could be interpreted as indicating that country differences in a selected indicator remain, but that those differences have reduced considerably (Liddle 2012, p.10).

The basic assumption of $\beta$-convergence is that countries with low initial levels of a selected indicator tend to grow comparatively faster than those with high initial levels and thus catch up with developed nations (Adhikari and Chen 2014, p.94). In the long run, the low-performed countries catch up with the higher-developed ones. The detailed description (based on the Solow-model) of that is given by Major (2001). If the estimated value of $\beta$ is negative, this verifiies the presence of $\beta$-convergence. But $\beta$-convergence is a necessary but not sufficient condition for $\sigma$-convergence (Boyle and McMcarthy 1997a, 1997b; Liddle 2012; Hajko 2012).

Table 2 presents the calculation formula and the interpretation of the convergence indexes. 
Table 2 Convergence indicators

\begin{tabular}{|c|c|c|}
\hline $\begin{array}{l}\text { Convergence } \\
\text { indicator }\end{array}$ & Formula & Interpretation \\
\hline$\sigma$-convergence & $\begin{array}{l}\qquad \begin{array}{l}\frac{\sum_{i=1}^{n}\left(x_{i}-\bar{x}\right)^{2}}{n} \\
C V=\frac{\sigma}{\bar{x}} \\
C V_{t}<C V_{0}\end{array} \\
\text { where: } x_{i} \text { denotes the examined indicator } \\
\bar{x}=\text { arithmetric means of } x_{i} \\
\sigma \text { denotes the dispersion, } C V \text { is the coefficient of } \\
\text { variation. }\end{array}$ & $\begin{array}{l}\text { If the value of the } \mathrm{CV} \text { is decreasing } \\
\text { over time, } \sigma \text {-convergence is } \\
\text { verified across the countries. }\end{array}$ \\
\hline$\gamma$-convergence & $\begin{array}{l}\qquad \gamma=\frac{\operatorname{Variance}\left(A R(I)_{i t}+A R(I)_{i 0}\right)}{\operatorname{Variance}\left(2 * A R(I)_{i 0}\right)} \\
\text { where: } A R(I)_{i t} \text { is the rank position of } i \text { country in } t \\
\text { current period, } A R(I)_{i 0} \text { is the rank position of } \mathrm{i} \\
\text { country in } 0 \text { base period. } \\
\qquad \text { Variance }=\frac{\sum(x-\bar{x})^{2}}{(n-1)} \\
\text { where: } \bar{x} \text { is the mean, } n \text { denotes the sample size. }\end{array}$ & $\begin{array}{l}\text { The smaller the value of the } \\
\text { indicator, the stronger the shift } \\
\text { among the examined territorial } \\
\text { units. }\end{array}$ \\
\hline$\beta$-convergence & $\begin{array}{l}\qquad \Delta \ln y_{i}=\alpha+\beta \ln y_{i 0}+\varepsilon_{i} \\
\text { where: } y \text { denotes the examined indicator (such as } \\
\text { energy intensity), } \alpha \text { is the constant, } \beta \text { is the } \\
\text { coefficient, } O \text { is the base period, } i \text { is the index of } \\
\text { the examined country, } \varepsilon_{i} \text { is the error term (the } \\
\text { excepted value is zero) }\end{array}$ & $\begin{array}{c}\text { If } \beta \text { is negative, } \beta \text {-convergence is } \\
\text { verified across the examined } \\
\text { countries. }\end{array}$ \\
\hline
\end{tabular}

Sources: Boyle and McCarthy (1997a, 1997b), Nemes Nagy (2005)

The $\beta$-convergence concept can be approached in unconditional (absolute) or conditional way. In the unconditional approach, all economies are assumed to converge to a common pattern of energy use (or to any other selected indicator), while in the conditional approach these close to their own steady state (Burnett 2013).

Furthermore, the absolute convergence calculation is applied, because the European Union determined a joint equilibrium value when working out the Energy 2020 document. In this process the energy potentials, structural differences, expected price of the production factors, technological development, and existing regulations were considered as well. The question is whether the member states can approach to this artificially created common steady state?

An additional interpretation is given by the convergence clubs, which denote groups of economies that are classified based on a selected indicator (convergence can be observed within the club). The essence of this theory is that the growth paths of these countries are near each other, so these show quasi homogeneity with regard to social and economic factors (Kocziszky et al. 2014). The objective of these analyses is to create groups minimizing the 
differences within the groups and maximizing the differences among the clubs (Szendi 2013). The most important difference between conditional and club convergence is that in conditional convergence the examined economies move toward a common (global), and in club convergence the territorial units of a club move toward a local steady state. In club convergence the convergence process is "determined by the existing, initial conditions (which refer to the group of countries), not by the structural factors" (Gáspár 2010, p.2).

The existence of the club convergence in the European Union - originating from the results of the analysis of absolute $\beta$-convergence - is analysed by hierarchical cluster analysis. The applied technique is the Ward method, which is a method of variance based analysis. At the beginning of the process each component constitutes an independent cluster and the method merges compenents at each step. Ward's minimum variance criterion minimises the total within-cluster variance. In our study the data must be standardised because initially these present difference metric sclaes. The mean of the standardised scale is zero, its dispersion is 1 (Sajtos and Mitev 2007).

\section{RESULTS}

We utilise the Eurostat (2015) and the World Bank (2015) database to examine the presence of convergence in the 28 members of the European Union. We distinguish between the old ${ }^{8}$ and the new ${ }^{9}$ member states (in the footnote the codes used by the World Bank are included). On the one hand this is justified by the significant development gap (with regard to the GDP per capita) and the differences in the energy features deriving from the differences in their history. The tested indicators can be connected to the Energy 2020 goals:

- energy intensity of the economy (the ratio of the gross national energy use to the GDP at 2005 market price, unit: koe/1000 EUR - source: Eurostat);

- emission intensity (the ratio of the greenhouse gas emissions to the GDP PPS at 2011 market price, unit: 1t $\mathrm{CO}_{2}$ equivalent/1000 USD - source: World Bank);

- the share of renewable energy sources to final energy consumption (\%) - (source: Eurostat).

The examined time period for the energy and emission intensity is 2001-2012, but data on renewable energy can be accessed only from 2004 in the Eurostat database, so here the analysis includes the 2004-2012 time period.

\footnotetext{
${ }^{8}$ France (FRA), Germany (DEU), Belgium (BEL), Luxembourg (LUX), Netherlands (NLD), Italy (ITA), United Kingdom (GBR), Ireland (IRL), Denmark (DNK), Greece (GRC), Spain (ESP), Portugal (PRT), Austria (AUT), Sweden (SWE), Finland (FIN)

${ }^{9}$ Cyprus (CYP), Malta (MLT), Estonia (EST), Latvia (LVA), Lithuania (LTU), Poland (POL), Czech Republic (CZE), Slovakia (SVK), Hungary (HUN), Slovenia (SVN), Romania (ROM), Bulgaria (BGR), Croatia (HRV)
} 
Similar to the study of Adhikari and Chen (2014) we tested the inverse of the energy intensity and the ratio of the greenhouse gas emissions to the GDP in the $\beta$ convergence, because this avoids the situation where the increasing indicator actually shows deterioration (so the rise in the energy intensity index shows a decrease in energy efficiency, meaning the higher the indicator, the worse the use of the energy sources). Applying the inverse of these, the increasing index shows development and better performance. Furthermore, the inverse of energy intensity is called energy efficiency, and along this analogy the inverse of the ratio of the greenhouse gas (GHG) emissions to the GDP is the inverse of emission intensity.

Table 3 Main statistical data of the old and new European Union member states

\begin{tabular}{|c|c|c|c|c|c|c|c|}
\hline & \multicolumn{2}{|c|}{$\begin{array}{l}\text { Energy intensity } \\
\text { (koe/1000EUR) }\end{array}$} & \multicolumn{2}{|c|}{$\begin{array}{l}\text { GHG emissions } \\
(1990=100 \%)\end{array}$} & \multicolumn{2}{|c|}{$\begin{array}{l}\text { Share of renewable } \\
\text { energy sources to } \\
\text { final energy } \\
\text { consumption }(\%)\end{array}$} \\
\hline & & 2001 & 2012 & 2001 & 2012 & 2004 & 2012 \\
\hline \multirow{3}{*}{ mean } & EU-28 & 298.87 & 221.86 & 94.10 & 86.08 & 11.38 & 16.87 \\
\hline & $\begin{array}{lll}\begin{array}{l}\text { EU-15 } \\
\text { states) }\end{array} & \text { (old member } \\
\end{array}$ & 159.91 & 136.49 & 109.07 & 93.50 & 11.98 & 18.44 \\
\hline & New member states & 437.82 & 307.23 & 79.14 & 78.67 & 10.79 & 15.31 \\
\hline \multirow{3}{*}{ median } & EU-28 & 197.40 & 166.35 & 98.73 & 84.25 & 7.65 & 13.65 \\
\hline & \begin{tabular}{|lll} 
EU-15 & (old member \\
states)
\end{tabular} & 159.60 & 139.65 & 104.68 & 89.59 & 7.60 & 13.65 \\
\hline & New member states & 432.85 & 295.15 & 77.64 & 65.51 & 8.30 & 13.75 \\
\hline \multirow{3}{*}{ minimum } & EU-28 & 103.30 & 82.80 & 40.50 & 42.92 & 0.30 & 2.70 \\
\hline & \begin{tabular}{|lll} 
EU-15 & (old member \\
states)
\end{tabular} & 103.30 & 82.80 & 85.26 & 76.55 & 1.20 & 4.20 \\
\hline & New member states & 147.40 & 133.80 & 40.50 & 42.92 & 0.30 & 2.70 \\
\hline \multirow{3}{*}{ maximum } & EU-28 & 1040.10 & 669.90 & 144.72 & 156.90 & 38.70 & 51.00 \\
\hline & \begin{tabular}{|lll} 
EU-15 & (old member \\
states)
\end{tabular} & 234.80 & 204.00 & 137.88 & 122.48 & 38.70 & 51.00 \\
\hline & New member states & 1040.10 & 669.90 & 144.72 & 156.90 & 32.80 & 35.80 \\
\hline \multirow{3}{*}{ dispersion } & EU-28 & 217.35 & 132.98 & 29.20 & 28.53 & 10.11 & 11.51 \\
\hline & \begin{tabular}{|lll} 
EU-15 & (old member \\
states)
\end{tabular} & 36.19 & 32.83 & 15.65 & 14.94 & 11.50 & 13.52 \\
\hline & New member states & 235.00 & 141.26 & 32.30 & 36.72 & 8.91 & 9.32 \\
\hline
\end{tabular}

Source: own compilation using Eurostat (2015)

Table 3 shows with simple statistic description the trends of the three selected indicators between 2001 (2004) and 2012. Significant development in the energy intensity can be observed, with the index improving in the old and in the new members as well. In the case of greenhouse gases Energy 2020 sets the goal with regard not to the intensity but to the emissions of base year 1990. Currently, we examine this indicator, but being a fixed-base index we can not take this into consideration in the following analysis (so we focus on the 
similar emission intensity). The emission data generally improved according to descriptive statistics (but more slowly than the energy intensity); however, the minimum and maximum values worsened (the minimum value was for Latvia, the maximum Malta and Cyprus). This affects the dispersion of the new members, which show a high increase, more than $13 \%$. The share of renewables developed in spite of the increasing dispersion of the member data.

\section{Convergence calculations in energy intensity}

The $\sigma$-convergence in energy intensity is verified until 2008 in the whole integration and in the new members as well. But in 2009 these positive process turn back, a slight divergence can be observed and the country differences increase. The main reason is that the energy intensity of the economy deteriorates in 10 members, while in the others it develops. One year later (of these 18 developing members) only Greece, Spain, and Cyprus are able to improve efficiency, but we note that this is almost certainly due to the economic downturn. However, this tendency is only temporary; after 2011 these trends cease, and energy efficiency becomes general in Europe. Among the old members the data dispersion does not change, the disparities become permanent. The presence of $\gamma$-convergence can not be verified in the integration (it can be explained by the short time period), so it can be stated that the differences across the tested units remain (the extent of mobility within the distribution is not significant), but the size of the differences decreased between 2001 and 2012 (Fig. 1).

Figure $1 \gamma$ and $\sigma$-convergence in the energy intensity

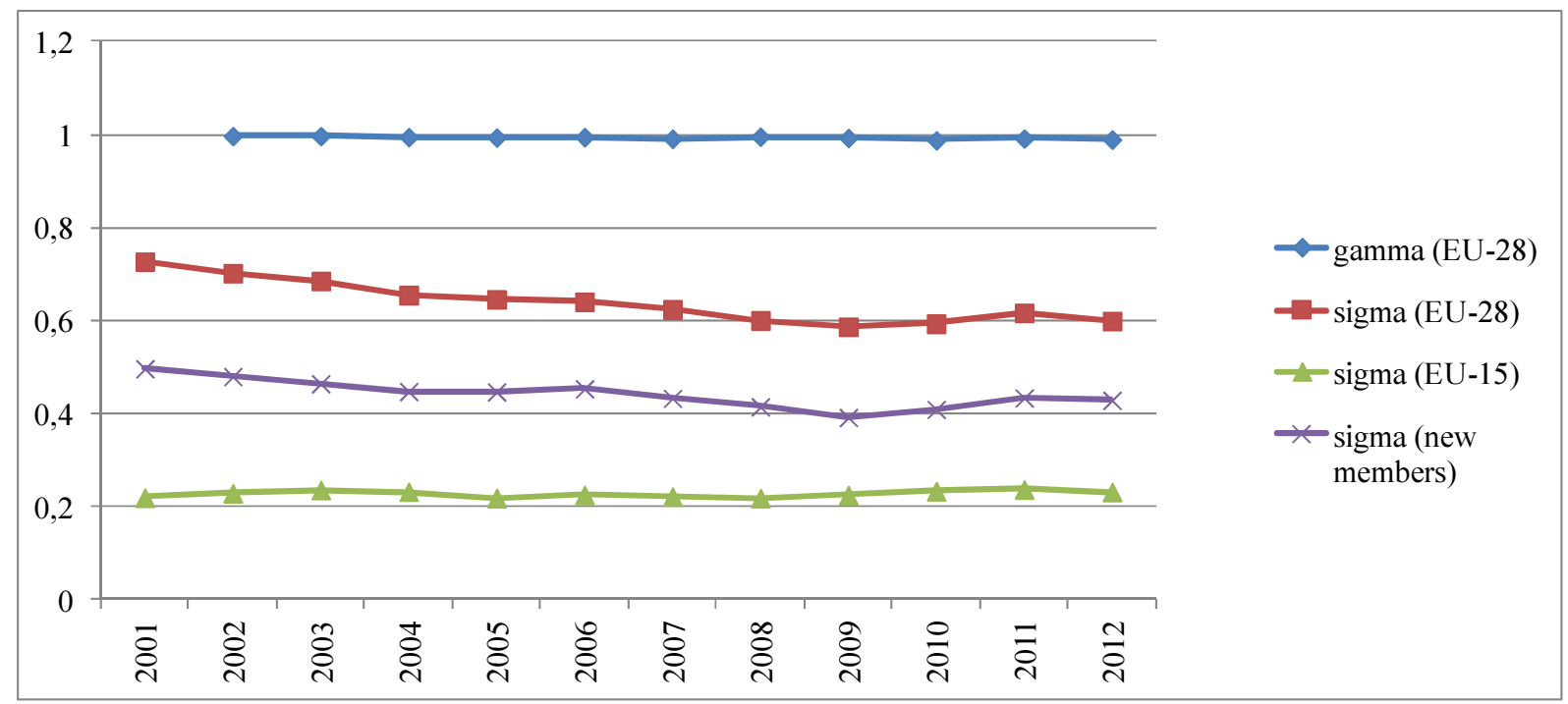

Source: own compilation 
With regard to the investigated 12 years there is negative relationship between the initial energy efficiency and the changes in it, so the calculated $\beta$ coefficient obtained from the regression equation shows the catching up of the lower-performing countries in the integration and also in the new members (the $\beta$-convergence is verified). This relationship is much stronger in the nations that joined the European Union in 2004, 2007 or 2013 than in the whole integration. Among the old members the $\beta$ coefficient is not significant (Table 4).

Table $4 \beta$-convergence in the energy efficiency of the EU-28

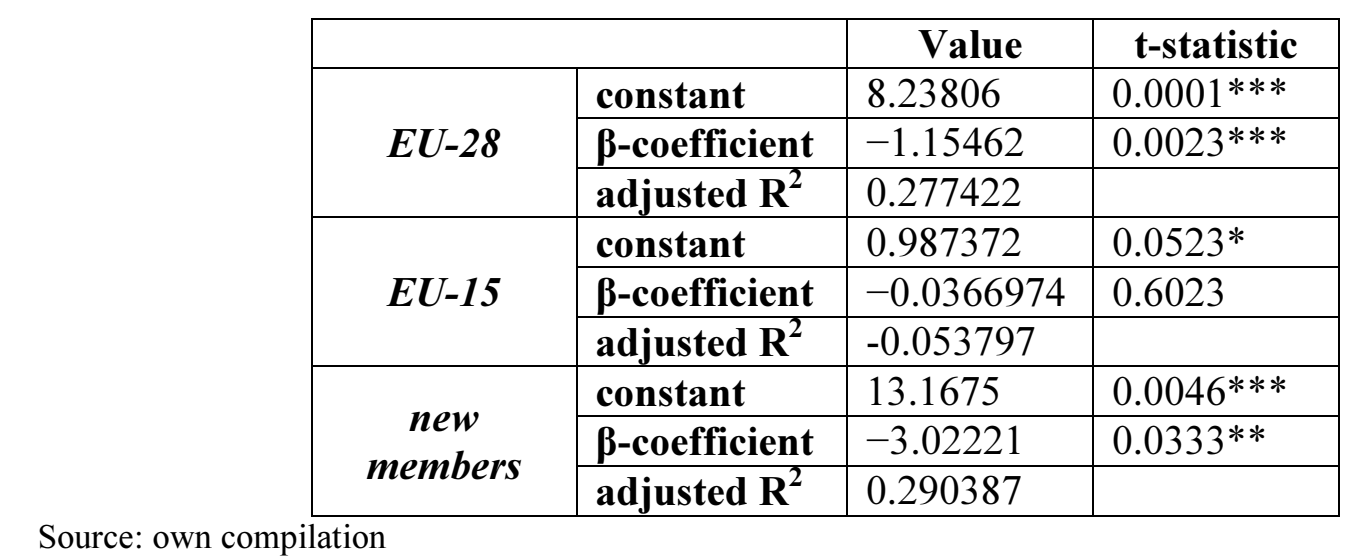

Because the presence of $\beta$-convergence is proved in the integration between 2001 and 2012, we identified the convergence clubs. The calculations were made for both three and four clusters (Fig. 2 shows results for both). In both cases Bulgaria forms an independent cluster, because its energy efficiency was really low in 2001, but it performed very well (we note that it is much easier to develop from a low initial level). The second cluster includes Romania, the Czech Republic, Hungary, Poland, Slovakia, Estonia, Latvia, and Lithuania. These nations are characterised by low initial energy efficiency (the index of GDP to energy consumption is lower than in the next cluster) and the shift is only slight. The following cluster can be divided into two subclusters (depending on the optimal number of the clusters): one of the subclusters includes Belgium, Finland, Sweden, Cyprus, Croatia, Malta, and Slovenia, while the other contains Ireland, Greece, Spain, France, Italy, Luxembourg, Netherlands, Austria, Portugal, United Kingdom, Denmark, and Germany. The energy efficiency of the former countries show better values compared to the first and second cluster, but the size of the shift is lower. The members of fourth cluster are the best performing countries, but we can observe stagnation. 
Figure 2 Convergence clubs in energy efficiency

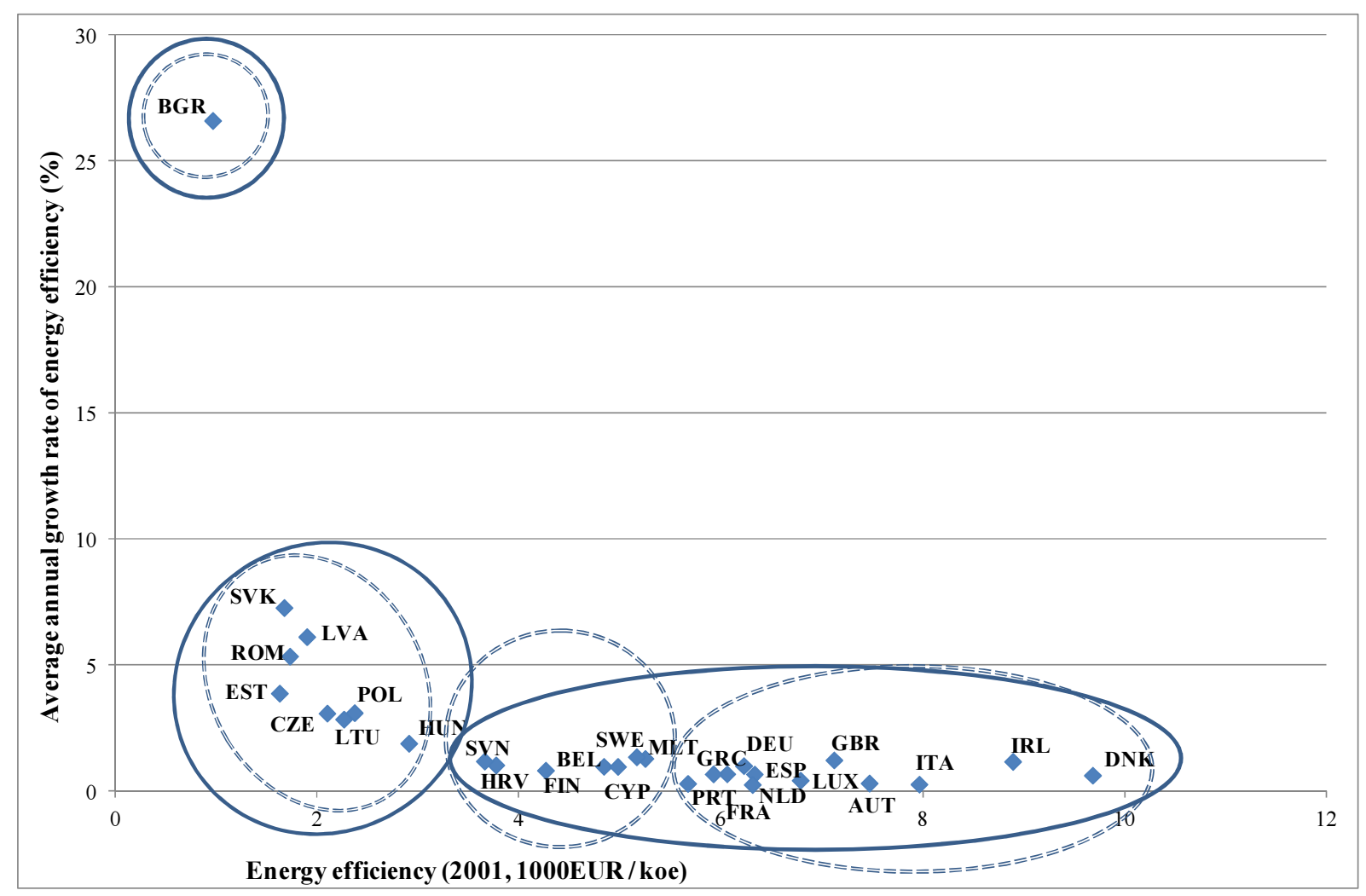

Source: own compilation

\section{Convergence calculations in GHG emissions}

A declining tendency can be observed in the trends of the emission intensity dispersion $(\sigma-$ convergence) between 2001 and 2008, which suggests that the disparities decreased for the current period, so there is convergence. From 2009 these promising processes turn back and the divergence becomes stronger, but it is only a temporary time period. In this short time period (2009-2010) 10 members are able to improve the indicator in spite of the economic crisis. In the others in almost one year the index increases. However in 2011 in Bulgaria, Greece, Spain, and Portugal the emission intensity continues to deteriorate. The main reason is that in these countries the rate of decline in the GDP has exceeded the decline in greenhouse gas emissions.

The presence of $\gamma$-convergence can be verified, but the process is weak, and the mobility of distribution is restrained in the 12-year time period (Fig. 3). 
Figure $3 \gamma$ and $\sigma$-convergence in emission intensity

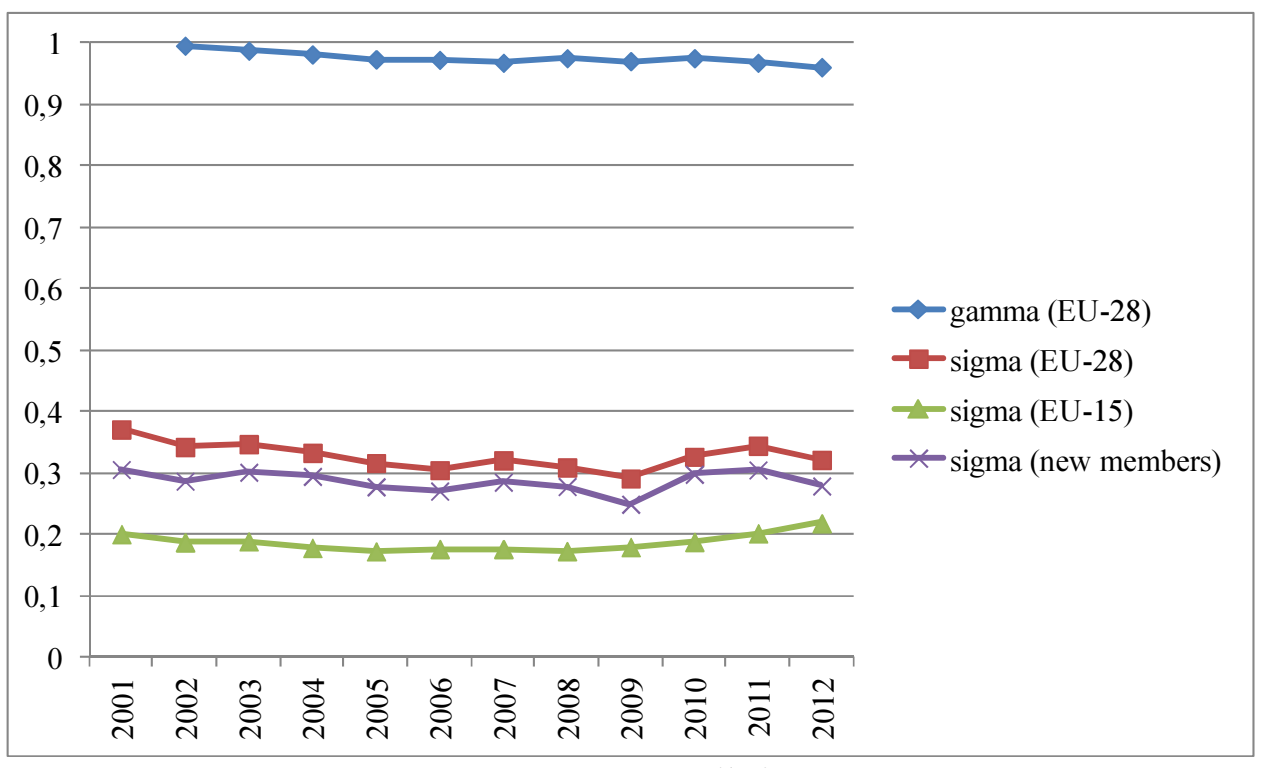

Source: own compilation

For the $\beta$ coefficient of the regression the countries with worst initial emission intensity tend to converge faster to the long-term steady state, so the growth rate of the poorly performing nations is higher, which confirms the occurrence of convergence in the European Union. This result is fit for the consequences of $\sigma$-convergence mentioned above. With the new members these trend is much stronger, but among the old members the $\beta$ coefficient can not be interpreted (it is not siginificant even at the $10 \%$ level), as in the case of energy efficiency (Table 5).

Table $5 \beta$-convergence in the emission intensity of the EU-28

\begin{tabular}{|c|c|c|c|}
\hline & & Value & t-statistic \\
\hline \multirow{3}{*}{$E U-28$} & constant & 9.69192 & $0.000 * * *$ \\
\hline & $\beta$-coefficient & -2.43910 & $0.000 * * *$ \\
\hline & adjusted $R^{2}$ & 0.614274 & \\
\hline \multirow{3}{*}{$E U-15$} & constant & 3.60041 & $0.0026 * * *$ \\
\hline & $\beta$-coefficient & -0.519040 & 0.1138 \\
\hline & adjusted $\mathbf{R}^{2}$ & 0.118070 & \\
\hline \multirow{3}{*}{$\begin{array}{c}\text { new } \\
\text { members }\end{array}$} & constant & 14.0096 & $0.000 * * *$ \\
\hline & $\beta$-coefficient & -4.51093 & $0.000 * * *$ \\
\hline & adjusted $\mathbf{R}^{2}$ & 0.833848 & \\
\hline
\end{tabular}

Source: own compilation

We calculated the convergence clubs to the inverse of the emission intensity, similarly to energy intensity. Three and four clusters were created. Sweden forms an independent group in both cases, because here the greenhouse gas emissions to GDP are extremely low, and furthermore continous development can be observed in the 12 years under investigation. The 
second club (if we determine four clusters) includes Denmark, Germany, Spain, France, Italy, Luxembourg, Netherlands, Austria, Portugal, and Malta. The emission intensity of these countries is very good and it improved slightly over the period.

The members of the next club are: Belgium, Ireland, Greece, Finland, United Kingdom, Cyprus, Croatia, Latvia, Lithuania, Hungary, and Slovenia. The emission intensity of these countries is moderate, but it is coupled with significant improvement. Poland, Slovakia, Estonia, Bulgaria, Romania, and the Czech Republic belong to the group of best performers: these countries started from a very low intial level but they are in the forefront in 2012 (Fig. 4).

Figure 4 Convergence clubs in the inverse of the emission intensity

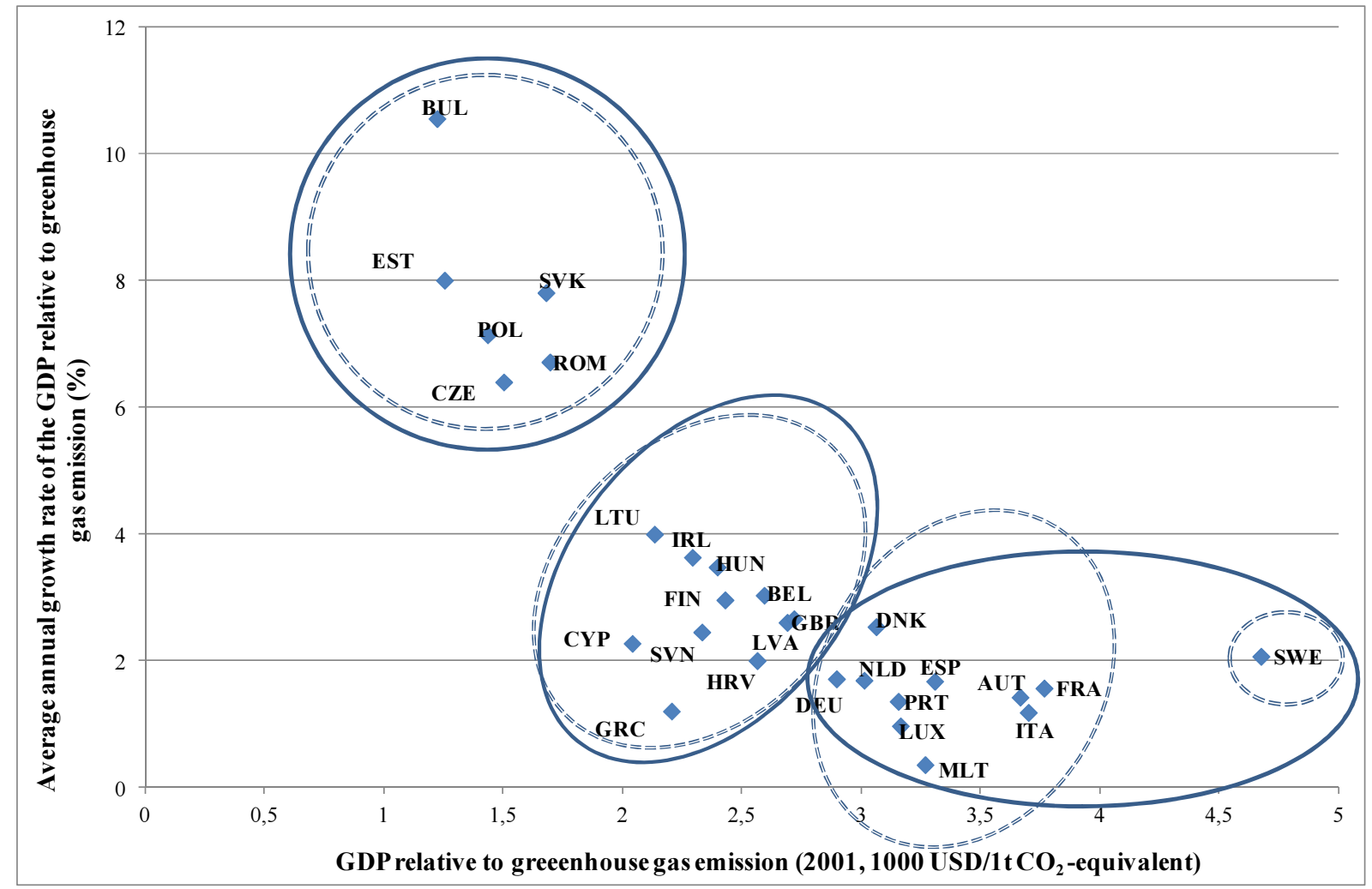

Source: own compilation

\section{Convergence calculations in the share of renewable energy sources}

Of the three selected indicators in this study, the convergence in renewable energy sources is the strongest, the decreasing in the differences here is the highest. It is interesting that the 2008-2009 financial crisis has not caused - unlike the other two indicators - a downturn or divergence in the European Union. One reason is likely to be that the already installed capacity continued to operate. On the other hand, this index can increase if the final energy consumption decreases and the energy use from renewables stagnates. The market of 
renewable energy sources - indirectly, through many other factors - is influenced by the oil prices and its effects on other instruments (for example the prices of gas prices and electricity highly depend on oil prices). In the summer of 2008 the oil price was at a record-breaking high (the WTI crude oil price exceeded 146 USD/barrel limit). In this market environment many oil and gas fired power plantsthat produced electricity expensively and inefficiently were shut down (such as Tisza II power plant in Hungary). At that time the payback period had become shorter for investments in renewables, which affected positively the installation of new capacity not only in the European Union, but in the whole world as well (the value of investments increased by $62 \%$ from 2006 to 2008 , according to the UNEP data). Thanks to the crisis the final energy use declined significantly (especially in the transport and industry sector), which accelerated the shutdown process of the old fossil-fuel power plants. Meanwhile renewable capacities have remained in operation, which strengthened the convergence of the European Union members (Fig. 5).

Figure $5 \gamma$ and $\sigma$-convergence in the share of the renewable energy sources

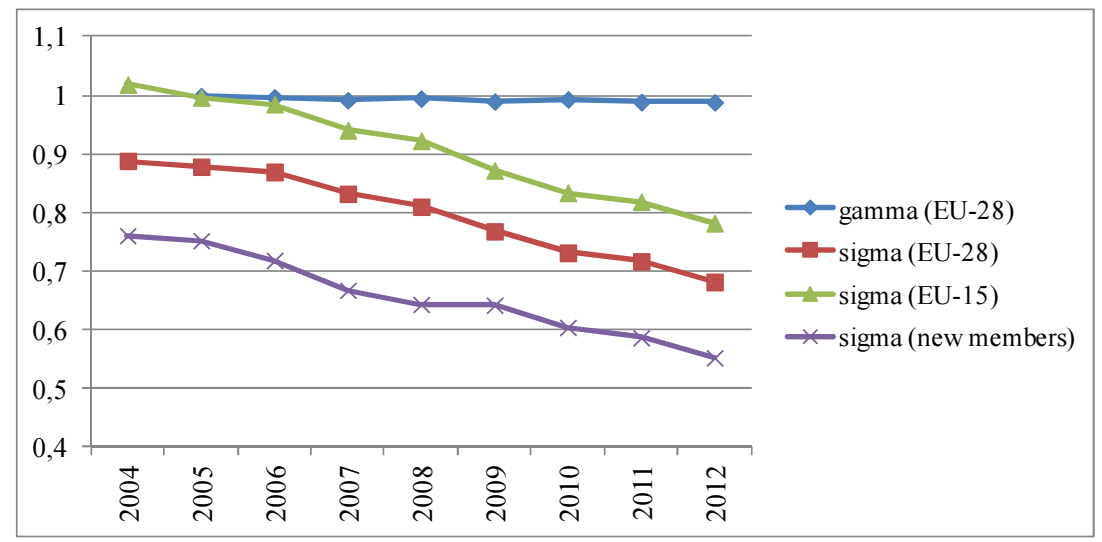

Source: own compilation

Similar to the energy intensity, the presence of $\gamma$-convergence cannot be proved, so it can be stated that differences remain but their dispersion decreased between 2004 and 2012.

The $\beta$ coefficient is negative in all cases, which confirms convergence. Countries with low initial values tend to grow faster, so the countries keep toward a common pattern of renewable energy use. With regard to the t-statistics, the factors are significant at the $1 \%$ level in the regression model (in the old and new members and in the whole integration). The value of adjusted $\mathrm{R}^{2}$ is moderately strong (Table 6). 
Table $6 \beta$-convergence in the share of renewable energy sources in the EU-28

\begin{tabular}{|c|c|c|c|}
\hline & & Value & t-statistic \\
\hline \multirow{3}{*}{$E U-28$} & constant & 9.90199 & $0.000 * * *$ \\
\hline & $\beta$-coefficient & -0.394818 & $0.0010 * * *$ \\
\hline & adjusted $\mathbf{R}^{2}$ & 0.330500 & \\
\hline \multirow{3}{*}{$E U-15$} & constant & 12.4832 & $0.0002 * * *$ \\
\hline & $\beta$-coefficient & -0.459776 & $0.0110 * *$ \\
\hline & adjusted $\mathbf{R}^{2}$ & 0.357341 & \\
\hline \multirow{3}{*}{$\begin{array}{c}\text { new } \\
\text { members }\end{array}$} & constant & 5.15710 & $0.000 * * *$ \\
\hline & $\beta$-coefficient & -0.200077 & $0.0009 * * *$ \\
\hline & adjusted $\mathbf{R}^{2}$ & 0.650723 & \\
\hline
\end{tabular}

Source: own compilation

Malta and the United Kingdom performed very well with regard to the ratio of consumption of renewables to total energy, so they form an indepent cluster. But we note that these countries had the lowest basic values (in Malta in 2004 the share of the renewable was only $0.3 \%$, in the UK $1.2 \%$ ), from where they could easily develop. The following group contains Finland, Latvia, and Sweden. These countries are generally environmentally conscious, and their renewables capacity was already remarkable in 2004. Their growth rate does not seem to be high, but in spite of that the capacity rise is serious (because of the high initial level).

Malta and the United Kingdom performed very well with regard to the ratio of consumption of renewables to total energy, so they form an indepent cluster. But we note that these countries had the lowest basic values (in Malta in 2004 the share of the renewable was only $0.3 \%$, in the UK $1.2 \%$ ), from where they could easily develop. The following group contains Finland, Latvia, and Sweden. These countries are generally environmentally conscious, and their renewables capacity was already remarkable in 2004. Their growth rate does not seem to be high, but in spite of that the capacity rise is serious (because of the high initial level).

Denmark, Austria, Portugal, Estonia, Croatia, Lithuania, Romania, and Slovenia form the third cluster. The basic value of these countries is about $15-2 \%$ in 2004 , an increase of $5-10$ percentage point to 2012 .

The last cluster has the largest number of elements: it includes Belgium, Ireland, Germany, Greece, Spain, Luxembourg, the Netherlands, France, Italy, Bulgaria, the Czech Republic, Cyprus, Hungary, Poland, and Slovakia. This cluster is characterised by a low initial level coupled with a high growth rate (Fig. 6). 
Figure 6 Convergence clubs in the share of renewable energy sources

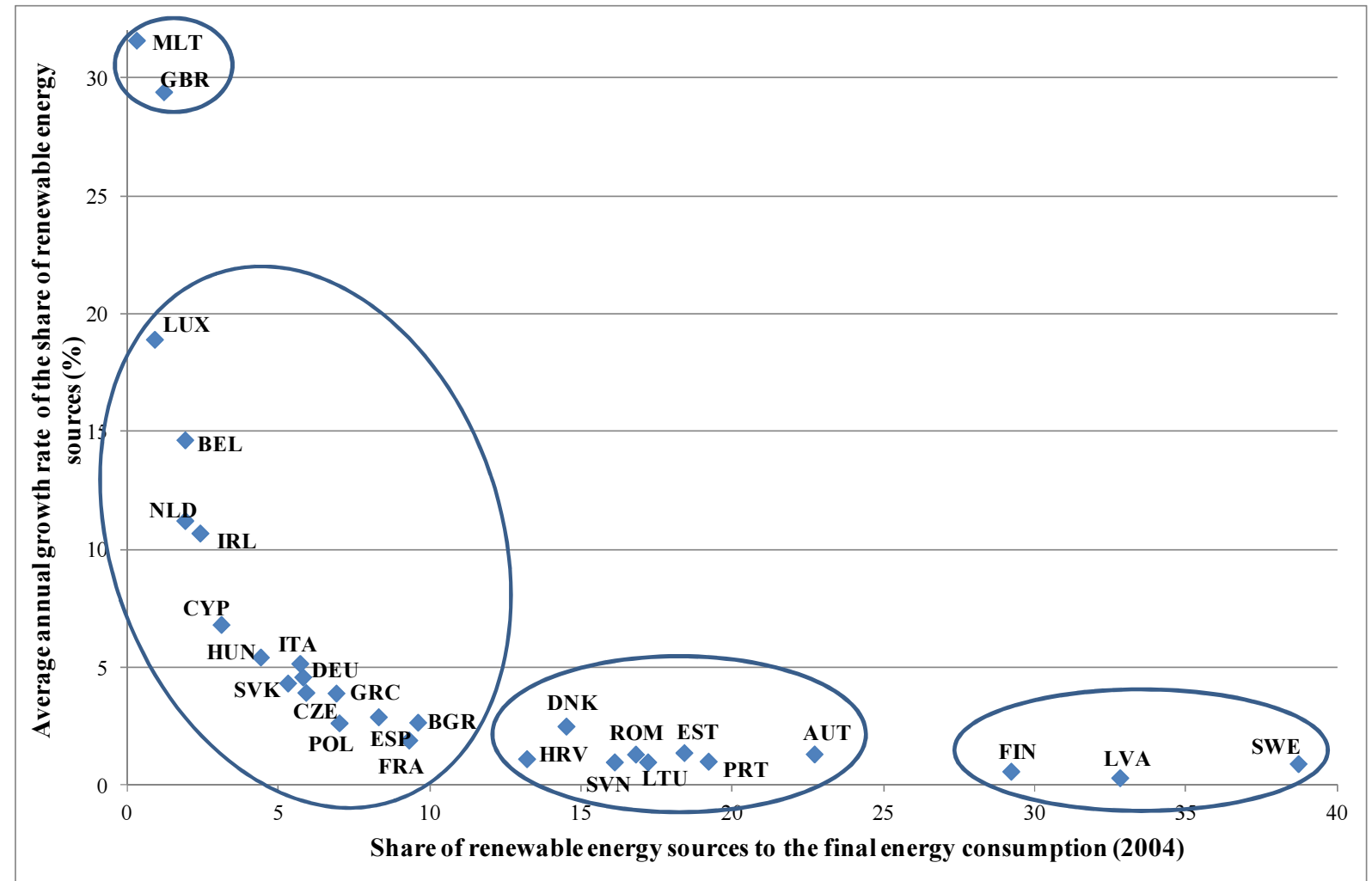

Source: own compilation

\section{CONCLUSION}

The 20-20-20 goals for energy intensity, share of renewable energy sources and the emissions complement each other very well, but examining progress being made toward meeting the goals is extremely important not only for decision makers, but for economic players as well. With adequate feedback the applied toolbar can be developed and expanded, and its effectiveness can be measured. In this study the presence of sigma, gamma, and absolute beta convergence was examined for these three energy indicators in the 28 member states of the European Union between 2001 and 2012. Furthermore, convergence clubs gave a useful additional perspective.

After carrying out the analysis we can make the following statements: 1) Sigma convergence can be proved in all of the examined indicators in the European Union. However the extremely weak presence of gamma convergence can be verified only in emission intensity. This means that the country differences remain between 2001 and 2012, but that those differences have reduced significantly. 2) The sigma convergence calculations in energy and emission intensity indicate the year 2009 to be a turning point, a so-called structural break. Convergence is replaced by divergence, but only temporarily (for 2 years). 3) Beta 
convergence indicates that the countries with low (poor) initial levels of the selected indicator are catching up to the better performing countries. 4) The results of sigma and beta convergence call attention to the significant differences between the new and old member states. In the energy and emission intensity convergence calculations it was found that the sigma and beta convergence is much stronger for the new members than in the whole integration. At the same time, in the old members the $\beta$ coefficient is not significant by these cases and the sigma convergence shows the persistence of the disparities. So those countries that have a weak initial level of energy efficiency and emissions (the new members) tend to grow comparatively faster than those with high initial levels (the new members). 5) The sigma and beta convergence calculations support the finding that the convergence in the share of the renewable energy sources is the strongest of the three examined indicators. 6) In the convergence club calculations the groups formed are arranged into the old and new members. 7) The convergence calculation methods are appropriate to control the national environmental processes. It can be stated that differentiated environmental policies should be applied with regard the old and new members.

The results should be taking into account when the European Union countries set up the new climate and energy objectives to 2030. Especially the members' clusters (the results of the convergence club calculations) should be considered and it is appropriate to determine the national target numbers (and the related national environmental and energy policies) with regard the cluster groups.

It is important to note that long-term conclusions about the energy convergence need more than 12 years of data, and the analysis of the conditional beta convergence is necessary. We set the objective to do this in the near future, in the next phase of our study. However, the current analysis can provide insight into the current processes, thus helping to monitor the progress towards the the 20-20-20 goal and to give feedback.

\section{Acknowledgement}

The described work was carried out as part of the TÁMOP-4.2.1.B-10/2/KONV-2010-0001 project in the framework of the New Hungarian Development Plan. The realization of this project is supported by the European Union, co-financed by the European Social Fund.

\section{REFERENCES}

Adhikari D., Chen Y. (2014). Energy productivity convergence in Asian countries: a spatial panel data approach International Journal of Economics and Finance 6. 7. pp.94-107. http://dx.doi.org/10.5539/ijef.v6n7p94

Adkins L. C. (2011). Using Gretl for Principles of Econometrics, 4th Edition Version 1.0471 p. 
Barro, R. J. (1991). Economic growth in a cross-section of countries Quarterly Journal of Economics 106. pp.407-443. http://dx.doi.org/10.2307/2937943

Barro, R. J., \& Sala-i Martin, X. (1992). Convergence J. Polit. Econ. 100. pp.223-251 http://dx.doi.org/10.1086/261816

Bartke, I. (1987). A területi hatékonyság és jövedelemtermelö képesség változásának számitása az iparban (in English: The calculation of the spatial efficiency and the potential for income production in the industry sector) Tér és Társadalom 1987/3. pp.3-22.

Bauer, T. (1981). Tervgazdaság, beruházás, ciklusok (in English: Planned economy, investment, cycles) Economics and Law Publisher: Budapest $182 \mathrm{p}$.

Benedek, J., Veress, N. (2013). Economic Disparities and Changes in the Convergence of the Romanian NUTS2 and NUTS3 Regions Romanian Review of Regional Studies: Journal of the Centre for Regional Geography, 9:(1) pp.85-90.

Boyle, G. E., McCarthy, T. G. (1997a). A simple measure of beta-convergence Oxford Bulletinn of Economics and Statistics 59. 2. pp.257-264. http://dx.doi.org/10.1111/14680084.00063

Boyle, G. E., McCarthy, T. G. (1997b). A simple measure of convergence in per capita GDP: A note on some further international evidence National University of Ireland - Maynooth in its series Economics, Finance and Accounting Department Working Paper Series, n751197. https://ideas.repec.org/p/may/mayecw/n751197.html downloaded: 2015. január http://dx.doi.org/10.1080/135048599353041

Burnett, J. W. (2013). Club convergence and clustering of U.S. Energy-related $\mathrm{CO}_{2}$ emissions AAEA\&CAES Joint Annual Meeting https://ideas.repec.org/p/ags/aaea13/149578.html downloaded: 2015 January

Camarero, M, Picazo-Tadeo, A. J., Tamarit, \& C. (2013). Are the determinants of $\mathrm{CO}_{2}$ emissions converging among OECD countries? Economics Letter 118. pp.159-162. http://dx.doi.org/10.1016/j.econlet.2012.10.009

Csereklyei, Z., Mar Rubio Varas, M. D., \& Stern, D. I. (2014). Energy and economic growth: the stylized facts CCEP Working Paper 1417 https://ccep.crawford.anu.edu.au/sites/default/files/publication/ccep_crawford_anu_edu_au /2014-12/ccep1417.pdf downloaded: 2015 January

Cottrell, A., Lucchetti, R. (2011). Gretl User's Guide 288 p.

Eurostat Database (2015), downloaded: 2015 January http://epp.eurostat.ec.europa.eu/portal /page/portal/statistics/search_database

European Climate Foundation (2009). Energy Roadmap 2050 http://www.roadmap2050.eu/ downloaded: 2015 January

European Commission (2010). Energy 2020: A strategy for competitive, sustainable and secure energy COM/2010/0639 final downloaded: 2015 January http://eurlex.europa.eu/LexUriServ/LexUriServ.do?uri=CELEX:52010DC0639R\%2802\%29:HU:H TML

Ezcurra, R. (2007). Distribution dynamics of energy intensities: A cross-country analysis Vol.35, No. 10, pp.5254-5259 http://dx.doi.org/10.1016/j.enpol.2007.05.006

Gáspár, A. (2010). Klub-konvergencia mérése a világ országaiban (in English: Calculation of the club convergence in the world countries) $28 \mathrm{p}$. http://media.coauthors.net/konferencia/conferences/3/MKE.pdf downloaded: 2015 January

Hajko, V. (2012). Changes in the energy consumption in EU-27 countries Review of economics perspectives 12. 1. pp.3-21. http://dx.doi.org/10.2478/v10135-012-0001-y

Kocziszky, Gy. (2011). Opportunities and limits of economic convergence for Hungary EUROPEAN INTEGRATION STUDIES 8(1), 47-60. 
Liddle, B. (2009). Electricity intensity convergence in IEA/OECD countries: aggregate and sectoral analysis Energy Policy $37 . \quad$ pp.1470-1478 http://dx.doi.org/10.1016/j.enpol.2008.12.006

Liddle, B. (2012). OECD Energy intensity: Measures, trends and convergence Energy efficiency, 5 (4), 583-597. http://dx.doi.org/10.1007/s12053-012-9148-8

Major, K. (2001). A nemzetközi jövedelemegyenlötlenség dinamikája (in English: The dynamics of the international income inequality) Phd dissertation, Budapest 123p.

Markandya A., Pedroso-Galinato S., \& Streimikiene D. (2006). Energy intensity in transition economies: Is there convergence towards the EU average? Energy Economics Vol. 28, No. 1. pp.121-145. http://dx.doi.org/10.1016/j.eneco.2005.10.005

Meng M., Payne J. E., \& Lee J. (2013). Convergence in per capita energy use among OECD countries Energy Economics 36. pp.536-545 http://dx.doi.org/10.1016/j.eneco.2012.11.002

Mielnik O., \& Goldemberg J. (2000). Converging to a common pattern of energy use in developing and industrialized countries Energy Policy $28 . \quad$ pp.503-508. http://dx.doi.org/10.1016/s0301-4215(00)00015-x

Mohammadi, H., \& Ram, R. (2012). Cross-country convergence in energy and electricity consumption, 1971-2007 Energy Economics 34. pp.1882-1887 http://dx.doi.org/10.1016/j.eneco.2012.08.001

Moutinho V., Robaina-Alves M., \& Mota J. (2014). Carbon dioxide emissions intensity of Portuguese industry and energy sectors: A convergence analysis and econometric approach Renewable and Sustainable Energy Reviews 40. pp.438-449. http://dx.doi.org/10.1016/j.rser.2014.07.169

Mulder P., Groot, H. L. F. (2012). Structural change and convergence of energy intensity across OECD countries, 1970-2005 Energy Economics 34. pp.1910-1921 http://dx.doi.org/10.1016/j.eneco.2012.07.023

Nemes Nagy, J. (2005). Regionális elemzési módszerek (in English: Regional analysis methods) Regional Science Studies, MTA-ELTE Regional Science Research Group 258p.

Oblath, G., Szörfi, B. (2008). Makrogazdasági konvergencia az EU új tagországaiban (in English: Macroeconomy convergence in the new members of the European Union) in: Kolosi Tamás-Tóth István György (editor): Social Report 2008. pp.204-225., TÁRKI, Budapest, downloaded: 2015 January http://www.tarsadalomkutatas.hu/kkk.php?TPUBLA-814/publikaciok/tpubl_a_814.pdf

Quah, D. T. (1995). Empirics for Economic Growth and Convergence Discussion paper no. 253., Centre for economic performance, https://ideas.repec.org/p/cep/cepdps/dp0253.html http://dx.doi.org/10.1016/0014-2921(95)00051-8

Sajtos, L., \& Mitev, A. (2007). SPSS kutatási és adatelemzési kézikönyv (in English: Handbook of SPSS research and data anaylsis) Alinea Publisher, Budapest 393 p.

Stern, D.I., \& Cleveland, C.J. (2004). Energy and economic growth Rensselaer Working Papers in Economics, Encyclopedia of Energy, Academic Press, San Diego CA, pp.35-51. http://dx.doi.org/10.1016/b0-12-176480-x/00147-9

Stern, D. I. (2011). The role of energy in economic growth Annals of the New York Academy of Sciences, Issue: Ecological Economics reviews pp.26-51. http://dx.doi.org/10.1111/j.1749-6632.2010.05921.x

Szendi, D. (2013). The convergence process and the effects of the economic crisis in CentralEastern Europe ROMANIAN REVIEW OF REGIONAL STUDIES, Volume IX, Number 1. $6 \mathrm{p}$.

Szlávik, \& J. (2013). Sustainable economy (in English: Fenntartható gazdálkodás) Wolters Kluwer CompLex Publisher, Budapest 273 P. ISBN 9789632953458

Tóth, G., \& Nagy, Z. (2014). Same or Different Development Paths?: A Comparative Study of the Large Cities and Regions in Hungary REGIONAL STATISTICS 4:(1) pp. 100-119. 
Sebestyén Szép, T.

UNEP (2015). Global Trends in Renewable Energy Investment 2015

http://fs-unep-centre.org/publications/global-trends-renewable-energy-investment-2015 downloaded: 2015 October

Worldbank (2015). World Development Indicators database www.worldbank.org 